\title{
Teaching Civic Education to Learners through Best Practices
}

\section{Idayat Nike Balogun}

Department of Social Sciences Education, Faculty of Education, University of Ilorin, Ilorin, Nigeria, balogun.in@unilorin.edu.ng

\author{
Abdulraheem Yusuf \\ Department of Social Sciences Education, Faculty of Education, University of Ilorin, Ilorin, Nigeria, \\ yuabra25@gmail.com
}

\begin{abstract}
This paper is a deliberate effort aiming at sensitising teachers, students, parents and other stakeholders on the basic objectives of civic education in its introduction into senior secondary school curriculum and the need to obtain full potentials for constructivist theory in teaching and learning of the relatively new subject. The introduction of civic education to Nigerian senior secondary school was directed at cultivating and developing in learners the skills and attitudes to function as relevant citizens of their society. The writer noted that the teaching of civic education in Nigeria is yet to achieve the purpose of which the subject was introduced. Among the objectives of civic education is to highlight the responsibilities of the government to the people and vice-versa and to also cultivate in students of senior secondary school their duties and obligations to the society. Curriculum experts have certain roles to play in integrating standard into curriculum by developing a curriculum framework. Onus of implementing civic education curriculum lies in the efforts and determination of qualified teachers, these categories of teachers are those who has chosen and are convinced that teaching is their calling, and are ready to serve their country in that capacity. The type of teaching expected from these teachers should help the students emerge with an understanding of their country's history and most cherished values. This is to say that learning experience must allow the students to practically demonstrate what civic education has taught them in any situation.
\end{abstract}

Keywords: civic education, teaching, learners, constructivism, curriculum

\section{INTRODUCTION}

The new civic education curriculum which was developed for use at senior secondary school level of the educational system in Nigeria was launched in 2009 by the Nigerian Educational Research and development Council (NERDC). This curriculum innovation calls for effective classroom teaching techniques so as to reflect the quality and relevance which curriculum development in Nigeria needs. Curriculum exhibits the total experiences to which all learners must be exposed to, particularly the contents and performance objectives which are the concern of this write up. Therefore, teachers are saddled with the responsibilities to enrich the teaching of contents of civic education with relevant materials and information from their immediate environment and adapt learning experience to the need and aspirations of the society. This is to say that most essential principles in teaching any subject is what transpires between the teacher and the learners and not solely what the curriculum content says, teachers have the wherewithal here to make instructional choice to facilitate effective teaching of his/her subject, teacher is also responsible for the learning experiences to be employed for the 
realization of the purpose for which the subject is being taught, therefore teaching of civic education should not be projected to the students as a boring abstract subject, the students should perceived civic education to their everyday activities at anytime and everywhere. This is achievable because the contents of civic education are not dull, also the instructional materials, resources and techniques to be used by the teacher should inspire the students to learn civic education successfully. Jekayinfa, Mofoluwawo \& Oladiran (2010) pointed that "the success of the civic education curriculum poses a challenge to social studies teachers because there are no qualified civic education teachers on the ground and the curriculum contents of social studies and civic education are similar." However, the notable areas of differences between the two subjects are the introduction of emerging issues into the civic education, among which includes, HIV/AIDS, youth involvement cybercrime, drug abuse, human trafficking and so on. All these are current issues which are world concern. Oyeleke (2011) added that the issue of appropriateness and depth of citizenship education curriculum in Nigeria to help the learners to internalize the civic competence necessary for them to function as responsible citizens has been adequately taken care of by the newly introduced civic education. However one of the challenges facing the implementation of the new curriculum is the methodology employed by the teachers to teach the subject in the teaching and learning situation.

It should then occur to the teachers of civic education to employ and utilize various techniques and methods of instruction which would enable the learners to participate actively in activities that encourage critical thinking and discourage rote learning which can only earn students' academic grades only. Hoagland (2000) observed that teachers need to connect the content to the individual interests of the students, thus increasing students interests in the content and actively engaging them in the learning process. This demands utilising a variety of teaching techniques that can help engage students in learning process.

On teachers instructional practices for teaching civic education, the writer view that all schools have the potential of providing the best. However inadequate teachers seem to be the problem, and that there is need to boost the morale of teachers available regardless of the location of the schools as this would bring a significant achievement in education, Given the preceding, utilising various teaching techniques and styles effectively is considered as best practices. Therefore, the following sub-headings is discussed in this text: concepts of civic education; objectives of civic education; new approaches for teaching civic education and learning theories for the instructional practices for civic education.

\section{Concept of Civic Education}

It is imperative for teachers of civic education at any level of schooling and in any part of Nigeria to be able to conceptualised and communicate what civic education is to learners. Furthermore, the teacher should be able to make a proper choice of objectives, contents selection and appropriate techniques to teach the subject (i. e application of what is being taught to real life situations).

Civic education seeks to achieve certain general goals, such as imparting knowledge about democratic practices and institutions, instilling and cultivating the most important democratic beliefs and values and encouraging more active and informed political participation. Sebiomo (2011), points that "civic education emphasises obedience and respect for governing authority. Leaders are to be respected and followed; when these are practiced society will develop."

Civic education teaches values system in the society. Value is the actual worth of a thing or objects. It is also a mere personal measure of worth, such as how important an individual considers certain things, beliefs, principles or ideas people attach to things based on their sense of value, students are taught some values like integrity, truthfulness, fairness, responsibility, patriotism etc. They are also to know their importance of value system such as selection of making a decision and how it allows individuals to act in accordance with our value system such as making a decision and it allows 
individuals to act in accordance with our values. However civic education is conceptualised by different authors to portray what civic education is all about, which also serve as a guide to teachers of civic education:

Abisala (2004) conceptualised civic education as a body of knowledge which provides information and learning experience to equip and empower citizens to participate in democratic process. Mezieobi (1992) visualized civic education as the educative means in a sovereign state whereby the citizens or individuals become socially and politically aware, socially integrated into the social milieu, acquire social skills and competences become socially sensitive and actively participate in their social responsibilities for maximum productivity and development, all in the interest of the state.

Ajibade (2011) defined civic education as a school subject which prepares people of a country especially the young members to carry out their roles as citizens. Ajibade further stated that civic education is concerned with the knowledge, skills and values citizens need to function effectively as political participants in various settings. It aimed at building an informed, effective and responsible citizenry as well as cultivating in the citizens a sense of commitment to the fundamental values and principles essential for the improvement and preservation of the society to Ekwonwa (2010). Civic education is viewed as aiming to educate students to work toward the achievement of their country's national goals and in sharpening of peoples values. Ajibade (2011) defined civic education as school subject which prepares people for a country especially the young members to carry out their roles as citizens.

Okwenu \& Anyacho (2005) considered civic education as the type of education the individuals in the state receive for the positive development of ideas, beliefs, habits and attitudes cherished by the society to enable them to live as useful and effective members of the society. Oladele (2009) defines civic education as the type of education given to the citizens of a particular country to make them be active and functional citizens. Jekayinfa, Mofoluwawo \& Oladiran (2011) presents civic education as a subject which helps people to deal with the world around them more capable and confidently. They stressed further that it covers a wide range of issues, topics and legislation that impact on people's lives and daily living at all time. The subject prepares young people how to get the best out of their world. It also teaches them to stand up for their rights and opinions and how to help other people to do so. The writer in her own point of view opines that civic education is conceived as a body of knowledge imparted through selfless efforts of efficient and effective teachers and received by conscious learners to showcase the right type of values and attitude for the growth and building of society. From the above concepts of civic education, it suffices to submit that teachers and students are better informed about the aim and purposes of the introduction of civic education curriculum into the senior secondary school. It is also worthy of reference that the senior secondary school civic education curriculum is seriously oriented towards the development of social skills and attitudes which is also balanced with appropriate contents such as human rights, citizenship, democracy and national development and emerging issues. In general, the civic education curriculum pays attention to the achievement of the Sustainable Development Goals (SDGs) and the critical components of the National Economic Empowerment and Development Strategies (NEEDS).

\section{Objectives of Civic Education}

According to the Nigerian Educational Research and Development Council (2009). The objectives of civic education in senior secondary school (with a slight modification of few words) are to:

- $\quad$ promote the understanding of inter-relationship between man/woman, the government and the society; 
- $\quad$ highlight the structure of government, its functions and the responsibilities of government to the people and vice-versa;

- $\quad$ enhance the teaching and learning of emerging issues and

- $\quad$ cultivate in students their duties and obligations to the society

Note: word modified "Inculcate" is better used as cultivating because it is better to nurture and foster than to induce or teach repeatedly as if the student's brain is empty. This means "inculcate" is to incite or to induce while cultivate is to nurture or to foster.

Therefore civic education in Nigeria is better described as learning about

- differences between human and within the society

- $\quad$ rights and responsibilities of individuals at all levels and

- $\quad$ Nigeria history and democratic political system

However, active and participatory learning methods with applications to real-life situations are needed to achieve the above.

\section{New Approaches for Teaching Civic Education: A Paradigm Shift to Learner-Centred} Approach

At any stage, education will always be civic that is all form of education still relate to citizenship. Curriculum planner determines what should be taught while the implementation of curriculum lies in the efforts of teachers who ensure that students emerge with an understanding of their country's and most cherished values. Therefore, teacher professionalism has relevant significance in education in the sense that it affects the role of the teachers and his/her pedagogy (strategies of instructions) which eventually affects students' ability to learn effectively. The approaches are new because not every teacher make use of them and emphasis is being laid on the use of these approaches in the curriculum of civic education. The approaches are best described as a progressive or active method as it meets the need of modern instructional strategies.

\section{Role Play}

A role play occurred when an individual assumed the characteristics of another person in a dramatic form. It is a popular tool for teaching for describing the social situation as it relates to character development. NTI (2008) stated that this method of teaching does not require any form of rehearsal, no elaborate preparation and no scripts to memorise, also, this method is ideal for attitude development and improving communication skills. This method can be used to demonstrate leadership and followership qualities. Hence teachers attitude to the lesson is important here because through this method students' mimic teachers in their absence, this is to conclude that through attitudes they know about the teacher and this enables effective teacher becomes role model to the students.

\section{Inquiry Method}

This method is equally an active approach to the teaching and learning of civic education in which learners are the active agents in discovering ideas. It has to do with searching for knowledge, critical thinking about issues, finding answers to them and drawing necessary conclusion. In this approach students can be engaged in finding out effects of ethnicity on good governance, the teacher the students to highlights what good governance is, which has to do with rendering quality service and creating working relationships to the populace. Students are then left with finding the meaning of ethnicity and likened it to good governance when this is done the effects of ethnicity will come up 
spontaneously. In this method, teacher plays their own role by guiding the learners in learning the new knowledge and skills to gain a depth of understanding and a personal perspective through a wide range of sources of information.

\section{Dramatization}

This technique is one of the most operatives which can be used to encourage the students in learning; this technique gives room for greater participation of students in teaching-learning using their every sense organ. Dramatization is an effective method to be applied when it comes to teaching abstract concepts and values such as selflessness, honesty, leadership, followership etc.

This can be acted during teaching and learning; it refers to a process where learners are given the opportunity to express themselves creatively or artistically, it may involve drumming, singing, miming and other related activities that can bring excitement to students. It involves actors, actresses and specialization; dramatization requires adequate preparation if the desired objective is to be realized. Use of this approach enables the students to know their strength area; the teacher can then help the student to perfect this strength, by involving students who are less active in the class by extending to them a sense of belonging. This gives room for students to start the thinking and to make carrier choice, other notable advantages of dramatization is the respect of the opinion of others and attitude of cooperation would learnt by the students.

\section{Simulation Method}

Simulation is a simplified model of a real-world situation. It is usually used for teaching concepts and principles that are not easily observable such as theoretical concepts. They are dynamic and lively ways of presenting ideas, problems, issues and realities in our past and present societies. It is therefore expected that through this method, a situation will be created in which activities are presented as if they are real-life (Adekunle 1984).

Adegbija (2000) observed that a simulation is pretending to be a mock or to intimate a particular situation. This method is the creation of a model of the real world in which participants assume different roles and make decisions about issues raised as well as the difficulties encountered. It also involves opportunities for exploration, experimentation, commitment and decision making aimed at resolving important issues and problems human in his/her environment (NTI 2009). Simulation activities are practical exercises in which students apply role-playing and act what actually happens on a particular social occasion. For example, students may mock Nigeria National Assembly, mock the address of president Muhammadu Buhari to the Nigerian during the celebration of the independent day, and many more, while doing this, students develop in themselves fluent oratory and confidence in speaking and addressing people in multitude would be an easy task.

\section{Cooperative Learning}

Cooperative learning is conceptualized as a teaching and instructional techniques where students are put into groups to work on certain actions in order to encourage student's interaction (Slavin 1980). This is to say that cooperative learning is one of the learner's centred approach which allows the learners to learn and earn ideas from each other by achieving the purpose and objective of a certain area of discipline. Amita (2006) corroborate this by defining cooperative learning as a small but dedicated group of students who learn together and take advantages of each other expertise to achieve a common goal.

This instructional technique somehow shares a close boundary with the collaborating method. According to Yusuf (2004) "collaborating allows students to talk with each other and listen to all points of view in the discussion. It helps think in a less personally biased way." Heinich, Molenda, 
Rusell \&Smaldino (2002) on their own part explained that advocates of cooperative learning argued that learners need to develop skills in working together because their eventual workplaces will require teamwork. among notable advantages of this instructional technique is that basic and low-level learners are being carried along, when the teacher instil in the students essence of cooperative learning thereby the low-level learners are not being stigmatized the way it used to be in the olden days. This technique also provides enabling an environment for learners to learn at their own pace and have control over their learning.

However, the teaching of civic education needs to rely on broad range methods to teach democratic orientations and behaviours. Some methods are more active, for example, literature has revealed that dramatization and role-play are far more successful than other methods are regarding relating teaching/learning to real life issues. The method also needs to be adapted to goals and objectives; this is to that if the goal is to encourage a lasting change in democratic behaviour, then more active methods are required. Teachers of civic education be reminded that, no single method of teaching is the best. Therefore teachers are not only expected to mix or interchange the use of the above methods and approach for the teaching of civic education, but they must also be equipped with the proper understanding of each of the techniques so that the application and use of each method would meet the attainment of the objectives of civic education as one of the core subjects in Nigeria senior secondary school.

\section{Instructional Practices for Teaching Civic Education}

The ultimate goal of any teaching activity in all educational institutions is to facilitate effective learning and accurate understanding among learners. In order to ensure this, teacher's efforts must be fashioned towards some specific approaches. An approach is a general educational or instructional orientation founded on assumed theories of knowledge and values (philosophy), of learning (psychology) and society (sociology) and how the three interact harmoniously and progressively. An instructional approach is closely tied to a theory of teaching which is itself informed by relevant theories, thus, in the main foundational disciplines of philosophy, psychology and sociology, the two dominant instructional approaches which are themselves natural offshoots of two different theoretical perspectives within each of the foundational feeder discipline (Lawal 2004). Figuring out the most effective teaching strategies for the teaching of civic education is seeing as one of the difficult tasks the teachers of civic education needs to deal with so as to prevent the poor performance of the students in one hand and achieve the purpose of which the subject was introduced on the other hand. Yusuf (2004) noticed that the poor performance of students is due to overcrowded classrooms. He then suggested that the instructional strategy should be centred on ways of seeking the truth, which include those of problem approaches, problem detecting, problem-solving, learning by doing and learning by experience. All the above emphasis by different authors is to suggest a specific learning theory for the instructional practices for the teaching of civic education. However, among the few learning theories to be considered is constructivist's view of learning. Constructivism is not about a particular strategy of instruction; it is concerned with how learners construct knowledge out of their experience. Hence it is usually associated with those pedagogical approaches charged with promotion of active learning, that is. Learning by doing.

Constructivism concentrates on the active learning process in which learners construct new ideas, a concept based on their course of the event and previous knowledge. It suffices to define constructivism as an educational strategy which demands that learners comprehend better the communicable knowledge constructed by themselves. Wertsch (1997) asserted that, in constructivist perspective the learner is considered to be central in the learning process, and when learners are motivated, the learners exercise his/her determination, will and action to gather relevant information, convert it, formulate hypotheses, and test it via applications, interaction or experiences and draw veritable 
conclusion. (Catherine, 2004) Examine the extent to which teachers have improved their understanding of civics teaching and learning as a result of participation in a highly focused practical and academic teacher exchange programme. She found a pragmatic significance with regards to teachers' positive perceptions about the reliability of their professional development experiences and their ability to assume a supportive role in their regional teams in subsequent years of the programme. The constructivist tone of the exchange experience continued to ring strong on the part of the teacher, the teacher learned about the important role that civic education plays in the cultivation of positive values of their countries and citizens. This approach easily seeped into their thinking about their teaching. (Ozer, 2004) Also corroborated this by pointing that constructivism transform today's classrooms into a knowledge construction platform where information is absorbed, and knowledge is built by the learners. Where teacher serves as a facilitator and a guide who plans, organises, guides and provide directions to the learners who is responsible for his learning. The teacher supports the learners using suggestions which arise out of ordinary activities, by challenges that inspire creativity and with projects that allow for independent thinking and new ways of learning information. Students work in groups to approach problems and challenges in real-world situations, this, in turn, leads to the creation of practical solutions and a diverse variety of student product. Hence constructivism has as its' goal; helping learners 'learn how to learn'.

A good example of this is when teachers of civic education insist that students learn civic education by doing, by creating their own meaning for a concept or a term i. e asking students how they will decide on issues, students can be allowed in civic education classroom to pass judgement on erring student, wherein teacher sensitise students to apply civic education knowledge while passing the judgement, here critical thinking has been repose on the students through this instructional practices, which will also leads students to discover essence of teaching civic education. Also, rather than defining right attitude the teacher can ask the students to give their own ideas of what right attitude is, after various submissions by the students of their own understanding of right attitude the class would then narrow it down to the definition on which they could all agree. When teachers practically carried these out in their classroom instruction, this would be enough evidence that constructivism is an effective model for the teaching of civic education. It is imperative to support the above assertion. Among the supporters of constructivism as the best practices for the teaching of civic education include Oladiti (2011) who was of the view that constructivism teaching is based on the belief that learning occurs as learners are actively involved in the process of meaning and knowledge construction rather than passively receiving information, and this explains why the hallmark of constructivism is active involvement of learners in the process of learning as against the usual passiveness characterized by receiving information alone. Funderstanding (2008) also described constructivism as a philosophy of learning based on the premise that by reflecting on one's experiences, we construct our understanding of the world where we live in. Educational Broadcasting Corporation (EBC) (2004) sees a constructivist classroom as the one wherein focusses shifts from the teacher to the students. Therefore, it is no gainsaying that constructivism promotes building active learners capable of constructing knowledge through an active and mental process of development. On the part of Atherton (2009), constructivism is seen as the label given to some set of theories about learning that falls within cognitive and humanities views which recognises learners as an active partner with the teacher in the process of creating new ideas.

From the preceding, it suffices to say that the instructional practices for effective teaching of civic education has to do with teachers' self-conscious use of an effective constructivist model in teaching civic education, so as to achieve what Catherine (2004) described as "functional constructivism". Functional constructivism occurs when teachers combine the basics of constructivism (student-centred learning, student-generated meaning, and working with peers and experts).

Anatolian Journal of Education, April $2019 \bullet$ Vol.4, No.1 
However as far as Nigeria Education is concerned, many studies certify that some teachers contribute more to their student academic achievements than others, researchers need to do more to identify the specific teacher qualifications, characteristics and classroom practices that are most likely improve student learning as categorized by Goe and Stickler (2008).

Table 1

Three Lenses for Examining Teacher Quality

\begin{tabular}{ll}
\hline Category & Definition and example indicators \\
\hline Qualification & $\begin{array}{l}\text { Credentials, knowledge and experiences that teachers bring with them when } \\
\text { they enter the classroom, such as: }\end{array}$ \\
& $\begin{array}{l}\text { Coursework, grades, subject-matter education, degrees, test scores, } \\
\text { experience, certification(s), and evidence of participation in continued } \\
\text { learning (e.g. internship induction, supplemental training and professional } \\
\text { development) }\end{array}$ \\
\hline Teacher & $\begin{array}{l}\text { Attitudes and attributes that teachers bring with them when they enter the } \\
\text { classroom, such as: }\end{array}$ \\
& $\begin{array}{l}\text { Expectations for students, collegiality or a collaborative nature, race and } \\
\text { gender. }\end{array}$ \\
\hline Teacher & $\begin{array}{l}\text { Classroom practices teachers employ-that is the ways in which teachers } \\
\text { interact with students and teaching strategies they use to accomplish specific } \\
\text { teaching tasks such as: }\end{array}$ \\
& $\begin{array}{l}\text { Aligning instruction with assessment, communicating clear learning } \\
\text { objectives and expectations for students' performance, providing an } \\
\text { intellectual challenge, allowing students to explain what they are learning, } \\
\text { using formative assessment to understand what and the degree to which } \\
\text { students are actually learning, g active learning experiences, subscribing to } \\
\text { cohesive sets of best teaching practices. }\end{array}$ \\
\hline
\end{tabular}

\section{CONCLUSION}

Civic education is a subject that is tasked to equip the young as well as adult members in the society the values of responsibility, loyalty and accountability including transparency in governance. Civic education helps to operationalise the principles and practice of good governance in the areas of government responsiveness to needs of the people by improving their lives.

The emphasis of this writer, therefore, is that teachers of civic education should endeavour to employ all the instructional practices reviewed in this article to be able to achieve the objective of civic education and national objectives of Nigerian education. Hence, teachers of civic education should shift from usual passing knowledge through the use of lesson note, teacher centred method and questioning method. Hence, they should familiarize themselves with the new strategies of teaching civic education.

While the curriculum focuses on developing democratic citizenship skills and knowledge, the daily experiences of the students in the school should not be disassociated from the actual life experiences of democratic values, such as competitiveness, openness, popular participation, tolerance, loyalty and so on. Therefore, learning environment should encourage dialogue that allows analysis, decision making and compromise. Also, the teacher should organise the classroom and environment for democratic learning, establishing opportunities for open communication and respect. 
For teachers of civic education to teach with best instructional practices, it is recommended that teacher share the following unique set of qualities such as:

$\checkmark \quad$ A desire to educate young learners and act as a positive role model;

$\checkmark \quad$ Developing ability to work with students from different backgrounds and abilities;

$\checkmark \quad$ Interest in helping people learn;

$\checkmark \quad$ Excited interest in the subject;

$\checkmark \quad$ Strong interpersonal and organisational skills;

$\checkmark \quad$ The ability to work unsupervised;

$\checkmark \quad$ Resourcefulness, energy and patience and

$\checkmark \quad$ Modern learning device and technologies.

The family and the society, from where the students come to the school and reside, should live by example because the students learn faster by imitation. Honesty and truthfulness should be emphasised and practised in the families and the society as a whole. Chieftaincy titles should not be awarded people of questionable character.

There should be sanitisation of Nigerian political system so that leaders portray good examples that would not be incongruent with what is taught in the school.

\section{REFERENCES}

Abisala. (2004). Introduction to civic education for Nigerian students. Lagos: Omodara publishers.

Adegbija, M. V. (2000). Instructional media: A basic handbook. Ilorin: INDEMAC COMMUNICATION

Adekunle, M. O. (1984). Methods and resources in teaching social studies. Available in https://www.researchgate.net/publication/238619814_METHOD_AND----

Ajibade, I. O. (2011). Civic education: A veritable tool for promoting responsible citizenship in Nigeria. Nigeria Journal of Social Studies, 16(2), 69-73.

Amy, K. S., Constance, A. F., \& Michael, D. S. (2007). Best practices in civic education: Challenges in students' civic outcomes. The Pennsylvania State University.

Atherton, J. S. (2011). Learning and teaching: Experimental learning [online] retrieved 15 March 2017 from Learning and Teaching

Catherine, S. (2004). Banging the drums of civic education: Teachers transformation in civic education through International Exchange and Exploratory Participant Research Study. Niskayuna central school. Niskayuna.

Circle Working Paper (2007). Best practices in civic education. www.civicyouth.org

Educational Broadcasting Corporation. (2004). Constructivism as a Paradigm for Teaching and Learning. A workshop paper. Educational Broadcasting Corporation.

Goe, L., \& Stickler, L. M. (2008). Teacher quality and student achievement: Making the most of recent research. Available in http://www.tqsource.org/publications/March 2008Brief.pdf 
Heinich, R., Molenda, M., Rusell, J. D., \& Smaldino, S. E. (2002). Instructional media and technologies for learning ( $7^{\text {th }}$ ed.). New Jersey: Pearson Education, Inc.

Hoagland, M. A. (2000). Utilizing constructivism in the history classroom. Retrived 14 March 2011, from: http://www.eric.ed.gov.

Iyewarun, S. A. (1984). The teaching of social studies. Woye Press \& Books Industries (NIG). LTD. Ilorin.

Jekayinfa, A. A., Mofoluwawo, E.O., \& Oladiran, M. A. (2011). Implementation of Civic Education Curriculum in Nigeria: Challenges for Social Studies Teachers. Nigerian Journal of Social Studies. XIV(1). 147-155

Lawal, R. A. (2004). Approaches, methods, strategies, techniques and their interrelationship. In I. O. Abimbola, \& A. O. Abolade, Fundamental principles \& Practice of instruction. Ilorin: Department of Curriculum Studies and Technology, University of Ilorin, Ilorin.

Mezieobi, K. A. (1992) Themes in Social Studies Education in Nigeria, Owerri: Whyte and Whyte Publishers.

National Teachers Institute. (2008). Manual for the retraining of primary school teachers. Kaduna. NTI

NERDC. (2009). 9 Year basic education curriculum for civic education in Nigeria. National Educational Research Development Council.

Okewnu, O., \& Anyako, E. (2005). Effective citizenship education for moral regeneration. Zaria Journal of Studies 11(3), 102-105.

Oladele, O. (2009). The basic concept of civic education. Ibadan: Holad Publishers

Oladiti, A. A. (2011). Teachers views of the potentialities in promoting bation building in Nigeria. Nigeria Journal of Social Studies, 16(2), 73-82.

Oyeleke, O. (2011). Country report: Citizenship education and curriculum development. Nigeria Journal of Social Science Education,

Ozer, O. (2004). Constructivism in Piaget and Vygotsky. The Fountain Magazine. Issues, 48.

Ronald, V. M., \& Kathryn, M. O. (2001). Three methods for teaching the social studies to students through the arts. Available in http://www.educ.ualberta.ca/css_35_4/ARsocstud_through_arts.ht

Russell, W. B., \& Waters S. (2010). Instructional methods for teaching social studies: A survey of what middle school students like and dislike about social studies instruction. Journal for the Liberal Arts and Sciences, 14(2), 7-14.

Vaughan, W. (2002). Effects of cooperative learning on the achievement and attitude among students of color. The Journal of Education, 96(6), 359- 369.

Wertsch, J. V. (1997). Vygotdky and the formation of the mind. Cambridge

Yusuf, A. (2004). Effects of cooperative instructional strategy on students' performance in social studies. Nigeria Journal of Social Studies, VIII(1\&2), 23- 36. 